\title{
Effect of drying air condition and feed composition on the properties of orange juice spray dried powder
}

\author{
Kankanit Khwanpruk ${ }^{*}$, Chanida Akkaraphenphan, Patipan Wattananukit, Worakarn Kaewket, and Suttiphat Chusai \\ Food Engineering Department, Faculty of Engineering, King Mongkut's Institute of Technology Ladkrabang, Bangkok, Thailand
}

\begin{abstract}
This research aims to investigate the effect of inlet air humidity, drying temperature and feed composition on the properties of orange juice spray dried powder. Maltodextrin (DE10-12) was used as carrier material. Full factorial design was applied to this research. Inlet air with humidity of $10 \mathrm{~g} / \mathrm{kg}$ dry air and $20 \mathrm{~g} / \mathrm{kg}$ dry air, inlet drying air temperature of $140^{\circ} \mathrm{C} 160^{\circ} \mathrm{C}$ and $180^{\circ} \mathrm{C}$ and feed concentration of $40^{\circ}$ Brix which varied the weight ratio of orange juice solid content to maltodextrin of 1:3 and 1:4.5 were examined. All spray drying conditions were performed in replicate. Ascorbic acid, moisture content water activity, $\mathrm{pH}$ and product yield were analysed. Analysis of variance revealed that humidity of inlet air influenced significantly on product yield, moisture content, water activity. Besides, the quality of product in term of ascorbic acid content was affected significantly by drying temperature and fraction of maltodextrin. Higher drying temperatures lead to lesser of ascorbic acid content and the more fraction of maltodextrin used in feed, the more ascorbic acid content retained in product.
\end{abstract}

\section{Introduction}

In food industry, drying process is widely used for preservation of foods and shelf life stability. Dried powder by spray drying method has the benefit of good reconstitution, low water activity and moisture content that good for transport and storage [1]. However, stickiness on the drying chamber wall is one of the problem occurred in spray drying step. Fruit juices such as orange juice contain highly hygroscopic ingredients such as fructose, glucose and organic acids which have the low glass transition temperature that lead to stickiness problem in spray drying chamber [2]. Feed solution can be successfully dried with improvement of spray drying condition. This research aims to investigate the effect of inlet air humidity, drying temperature and feed composition on the properties of orange juice spray dried powder. Full factorial design was set to find the optimal spray drying conditions for high quality powders and production yields.

\section{Materials and Methods}

\subsection{Materials}

In this study, Concentrated orange juice with a total solids mass concentrationof $65.0 \pm 0.2 \%$, containing $3.0 \pm 0.2 \%$ Acid (as citric acid monohydrate), obtained from a local manufacturer, was used. maltodextrin with DE 10-12 (Maxway, Thailand)

\subsection{Feed preparation}

Orange juice concentrate of $65^{\circ}$ Brix concentration was adjusted with maltodextrin (DE10-12) and water, in order to make the constant feed concentration of $40^{\circ}$ Brix with the various mass ratio of Orange juice solid content to maltodextrin solution $1: 3$ and 1:4.5, respectively.

\subsection{Spray drying and experiment design}

\subsubsection{Spray drying}

Feed solution was dried by using a co-current spray dryer (JCM Minilab SDE-10, Thailand). The height of the spray dryer are $1.2 \mathrm{~m}$. An atomiser is two fluid nozzle type. The atomiser air pressure was set at 0.1 $\mathrm{MPa}$ using a peristaltic pum for conveying the liquid feed to the chamber. Temperature of drying air was set by using electrical heater. Drying air flow rate was set constantly at $108 \mathrm{~m}^{3} / \mathrm{h}$. Humidity of inlet air was controlled by using a dehumidified unit which coupled with a conventional spray dryer as shown in Fig.1.

\subsubsection{Experiment design}

Experiments were planned applying a full factorial design.

Corresponding author: kankanit.kh@kmitl.ac.th 


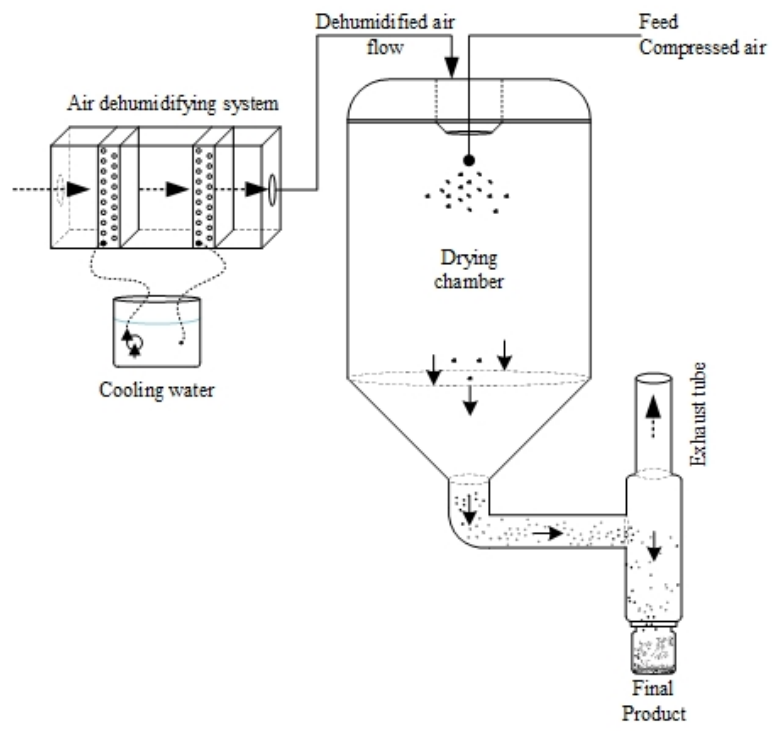

Fig. 1. Spray dryer with dehumidified system.

Inlet air with 2 levels of humidity of $10 \mathrm{~g} / \mathrm{kg}$ dry air and $19 \mathrm{~g} / \mathrm{kg}$ dry air, 3 levels of inlet drying air temperature of $140^{\circ} \mathrm{C} 160^{\circ} \mathrm{C}$ and $180^{\circ} \mathrm{C}$ and 2 levels of feed concentration of $40^{\circ}$ Brix which varied the weight ratio of orange juice solid content to maltodextrin (O:M) of $1: 3$ and $1: 4.5$ were carried out.

\subsection{Powder analysis}

\subsubsection{Production yield}

The production yield was expressed as a percentage of the mass of orange juice spray dried powder gathered at the collection product bottle compare to the solid contents of orange juice solution and maltodextrin solution.

\subsubsection{Moisture content and water activity $\left(a_{w}\right)$}

The moisture content of orange juice powder was evaluated by vacuum oven method (MMM, VACUCELL model) [3]. Drying period was set at $70^{\circ} \mathrm{C}$ for 24 hours.

Water activity of the orange juice powder was determined using a water activity meter (an AquaLab 3TE Decagon, USA). The temperature was kept at 25.0 $\pm 0.1^{\circ} \mathrm{C}$ during testing.

\subsection{3 pH measurement}

The $\mathrm{pH}$ values of orange juice solutions were analysed by using a $\mathrm{pH}$ metre (Consort C830, Belgium).

\subsubsection{Ascorbic acid content}

Ascorbic acid content was determined using the titration method modified from Kingwatee et al. (2015) [4]. In this context, spray dried orange powder was reconstitued to concentration of $40^{\circ}$ Brix and then $10 \mathrm{ml}$ aliquot was put into a volumetric flask and $90 \mathrm{ml}$ of $0.4 \%(\mathrm{w} / \mathrm{v})$ oxalic acid were added. Solution of $0.025 \%(\mathrm{w} / \mathrm{v}) 2,6-$ dichlorophenolindo phenol was used as a titrant. The end point of titration was a stable development of pink colour. L-ascorbic acid was used for construction a standard curve.

\subsubsection{Particle morphology}

Particle morphology was evaluated by scanning electron microscopy (SEM) ZEISS model EVO MA 10 at Instrument center of Advanced Manufacturing Innovation College, KMITL.

\subsubsection{Statistical analysis}

The experimental data were evaluated by using ANOVA (Minitab 16 software). The spray drying runs were carried out in duplicate and powder properties analysis were tested in triplicate. All data were reported as mean \pm standard deviation.

\section{Results and Discussions}

Spray drying experiments were run by setting 2 levels of inlet air humidity, 2 levels of feed concentration with the different ration of orange solid content to maltodextrin at the constant feed concentrations of $40{ }^{\circ} \mathrm{Brix}$ and a range of inlet drying air temperature $\left(140,160\right.$ and $\left.180^{\circ} \mathrm{C}\right)$. This experiments were used a constant feed concentration of $40^{\circ}$ Brix to control the amount of water evaporation. Humidity of drying air were set at 10 $\mathrm{g} / \mathrm{kg}$ dry air and $20 \mathrm{~g} / \mathrm{kg}$ dry air controlled by using the dehumidified system as shown in Fig. 1. The average humidity of drying air in this experiment was $10.42 \pm 0.24$ $\mathrm{g} / \mathrm{kg}$ dry air when using the modified spray dryer and was $19.07 \pm 1.55 \mathrm{~g} / \mathrm{kg}$ dry air when using a conventional spray dryer. The effects of orange juice solid content ratio and different humidity and drying air temperature on the production yield, moisture content, water activity, $\mathrm{pH}$ and ascorbic acid content of spray dried product and ANOVA tests are shown in Table 1.

\section{Production yield}

The production yield from a range of humidity, mass content ratios and drying temperatures studied was shown in Fig. 2. The resulting yields from these experiments were about 24- 64\%. In comparison with the yield from a small-scale spray dryer, this should be more than $60 \%$ to be acceptable [5]. Only products from using low humidity drying air showed an acceptable production yield. Fig. 2 shows an increasing yield from spray drying as the humidity of drying air decrease and illustrates an increase of the yield as the drying temperatures increase. ANOVA tests suggested that both the humidity and drying temperature affected the yield from spray drying significantly (Table 1). 
Table 1. Properties of orange juice powder under various conditions

\begin{tabular}{|c|c|c|c|c|c|c|c|}
\hline $\begin{array}{c}\text { Humidity } \\
\text { (g/kg dry air) }\end{array}$ & $\begin{array}{c}\text { Conc. } \\
(\mathrm{O}: \mathrm{M})\end{array}$ & $\begin{array}{c}\text { Inlet } \\
\text { temp. } \\
\left({ }^{\circ} \mathrm{C}\right)\end{array}$ & $\begin{array}{c}\text { Production } \\
\text { yield }(\%)\end{array}$ & $\begin{array}{l}\text { Moisture } \\
\text { content } \\
(\% \text { wb) }\end{array}$ & $\begin{array}{c}\text { Water } \\
\text { activity }\end{array}$ & $\mathrm{pH}^{*}$ & $\begin{array}{c}\text { Ascorbic acid } \\
\text { (mg/g } \\
\text { powder) }\end{array}$ \\
\hline \multirow{6}{*}{10} & \multirow{3}{*}{$1: 3$} & 140 & $37.79 \pm 0.91^{\text {cde }}$ & $1.59 \pm 0.21^{\mathrm{abc}}$ & $0.37 \pm 0.01^{\mathrm{ab}}$ & $3.05 \pm 0.02$ & $2.94 \pm 0.04^{\mathrm{a}}$ \\
\hline & & 160 & $62.28 \pm 4.88^{\mathrm{ab}}$ & $0.81 \pm 0.40^{\mathrm{c}}$ & $0.33 \pm 0.00^{\mathrm{bc}}$ & $3.07 \pm 0.03$ & $2.73 \pm 0.08^{\mathrm{ab}}$ \\
\hline & & 180 & $50.32 \pm 3.63^{\mathrm{bc}}$ & $0.55 \pm 0.20^{\mathrm{c}}$ & $0.31 \pm 0.01^{\mathrm{bc}}$ & $3.08 \pm 0.01$ & $1.47 \pm 0.04^{\mathrm{h}}$ \\
\hline & \multirow{3}{*}{$1: 4.5$} & 140 & $46.63 \pm 3.34^{\mathrm{c}}$ & $2.83 \pm 0.04^{\mathrm{a}}$ & $0.40 \pm 0.00^{\mathrm{a}}$ & $3.05 \pm 0.00$ & $2.50 \pm 0.19^{\mathrm{bcd}}$ \\
\hline & & 160 & $47.19 \pm 4.47^{\mathrm{c}}$ & $1.78 \pm 0.97^{\mathrm{abc}}$ & $0.32 \pm 0.01^{\mathrm{bc}}$ & $3.06 \pm 0.00$ & $2.39 \pm 0.00^{\text {bcde }}$ \\
\hline & & 180 & $63.98 \pm 1.83^{\mathrm{a}}$ & $0.98 \pm 0.19^{\mathrm{bc}}$ & $0.28 \pm 0.01^{\mathrm{c}}$ & $3.07 \pm 0.01$ & $1.96 \pm 0.11^{\text {efg }}$ \\
\hline \multirow{6}{*}{20} & \multirow{3}{*}{$1: 3$} & 140 & $24.95 \pm 2.41^{\mathrm{e}}$ & $1.89 \pm 0.28^{\mathrm{abc}}$ & $0.39 \pm 0.02^{\mathrm{a}}$ & $3.06 \pm 0.01$ & $2.63 \pm 0.04^{\mathrm{abc}}$ \\
\hline & & 160 & $45.15 \pm 0.43^{\mathrm{c}}$ & $1.43 \pm 0.50^{\mathrm{abc}}$ & $0.33 \pm 0.02^{\mathrm{bc}}$ & $3.07 \pm 0.00$ & $2.15 \pm 0.04^{\text {defg }}$ \\
\hline & & 180 & $43.59 \pm 1.28^{c}$ & $0.85 \pm 0.52^{\mathrm{c}}$ & $0.33 \pm 0.00^{\mathrm{bc}}$ & $3.10 \pm 0.00$ & $1.82 \pm 0.08^{\mathrm{gh}}$ \\
\hline & \multirow{3}{*}{$1: 4.5$} & 140 & $25.17 \pm 3.36^{\mathrm{de}}$ & $2.93 \pm 0.29^{\mathrm{a}}$ & $0.40 \pm 0.00^{\mathrm{a}}$ & $3.06 \pm 0.03$ & $2.39 \pm 0.11^{\text {bcde }}$ \\
\hline & & 160 & $38.61 \pm 3.63^{\mathrm{cd}}$ & $2.62 \pm 0.56^{\mathrm{ab}}$ & $0.39 \pm 0.01^{\mathrm{a}}$ & $3.08 \pm 0.02$ & $2.23 \pm 0.11^{\text {cdef }}$ \\
\hline & & 180 & $49.61 \pm 5.84^{b c}$ & $1.46 \pm 0.36^{\mathrm{abc}}$ & $0.28 \pm 0.04^{\mathrm{c}}$ & $3.09 \pm 0.01$ & $1.99 \pm 0.19^{\mathrm{efg}}$ \\
\hline
\end{tabular}

As the humidity of drying air decreased the yield was increased. This was caused by the drier air promoted a drying rate which improved the drying process by decreasing the stickiness problem [6]. As the drying temperature increased the yield was increased. This was caused by the lower moisture content of the powder at higher temperature, which reduced the high deposition of wet particles on the spray dryer walls [5]. However, for the sugar-rich feed spray drying, Goula and Adamopoulos (2010) reported that the production yield is largely affected by the inlet air temperature and the wall depositions increase by increasing the inlet air temperature [6].

Moisture content and water activity of orange juice powder

Spray dried Orange juice powders obtained from the experiments had moisture content in the range of 0.5 $2.9 \%(w b)$ as shown in Table 1. Fig. 3 shows a decrease of moisture content as the drying temperature was increased. High air inlet drying temperature increased the greater water evaporation, due to the higher rate of heat transfer to particles. ANOVA tests suggested that humidity and temperature of drying air temperature affect the moisture content and water activity of product significantly (Table 1). All of moisture content values obtained through this study were under the common observed value in industrial spray drying, which is lower than $5 \%$ [7]. Water activity is one of the most importance quality aspects for product storage and stabilityt. The average water activity values of between 0.28 and 0.40 , which considered as microbiology safe and oxidative stable [8].

\section{pH and Ascorbic acid content of orange juice powder}

The values of $\mathrm{pH}$ of the orange juice powders in this study were significantly affected by humidity and drying air temperature included the fraction of orange juice solid content to maltodextrin content $(\mathrm{p}>0.05)$. The $\mathrm{pH}$ values of the orange juice feed solution were $2.79 \pm$
0.01 for the O:M of $1: 3$ and the values of $2.81 \pm 0.01$ for the $\mathrm{O}: \mathrm{M}$ of $1: 4.5$.

$$
\begin{aligned}
& \rightarrow 1: 3,10 \mathrm{~g} / \mathrm{kg} \text { d.a. } \quad--13,20 \mathrm{~g} / \mathrm{kg} \text { d.a. } \\
& -1: 4.5,10 \mathrm{~g} / \mathrm{kg} \text { d.a. } \quad-4-1.4 .5,20 \mathrm{~g} / \mathrm{kg} \text { d.a. }
\end{aligned}
$$

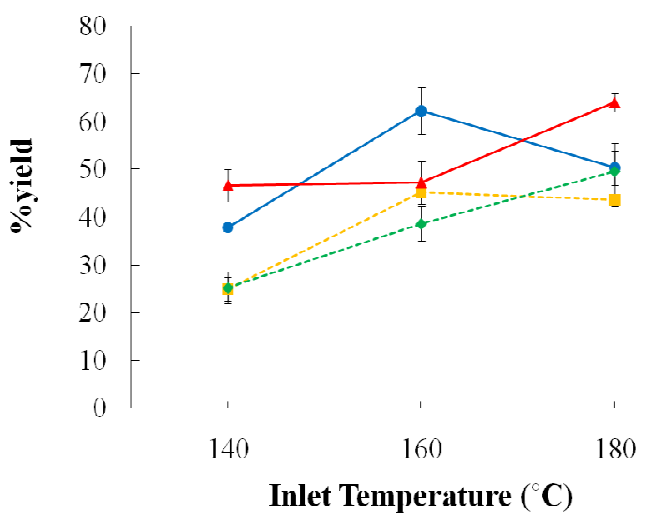

Fig. 2. Production yield from various spray drying conditions

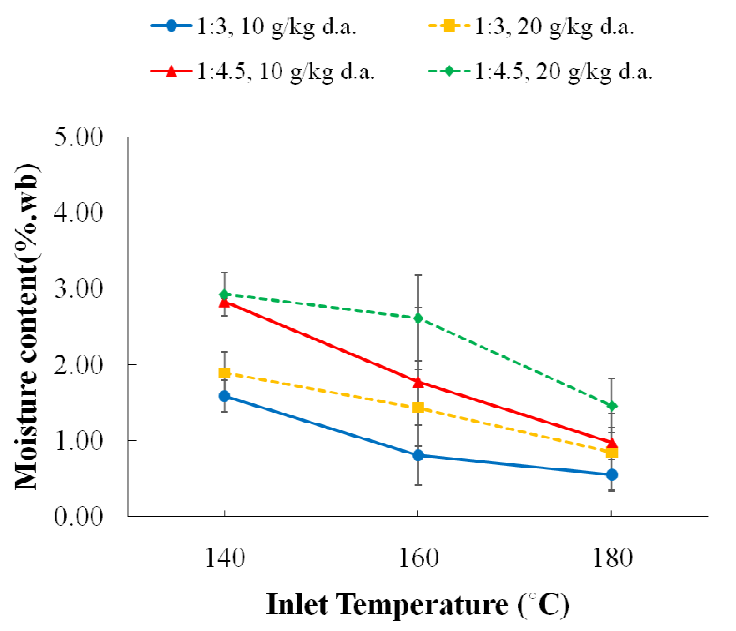

Fig. 3. Moisture content of orange juice powder from various spray drying conditions 
The $\mathrm{pH}$ values of the spray dried powder (3.05-3.10) were slightly higher than $\mathrm{pH}$ values of feed which means that the acidity of orange juice product was decreased by the spray drying process. As well as the ascorbic acid content was affected significantly by drying temperature and the content of maltodextrin as drying aid. Ascorbic acid content in feed solution was $4.85 \mathrm{mg} / \mathrm{g}$ feed solid for the O:M of $1: 3$ and was $3.39 \mathrm{mg} / \mathrm{g}$ feed solid for the $\mathrm{O}: \mathrm{M}$ of 1:4.5. The contents of ascorbic acid in products are shown in Table 1. The results show that ascorbic acid contents are decreased as the temperature increased because of a degradation of ascorbic acid by temperature during spray drying process [9]. The comparison between ascorbic acid content before and after the drying process can be shown as percentage of retention displayed in Fig.4. The results show that maltodextrin plays the role of ascorbic acid protection as the more maltodextrin contained in feed, the more ascorbic acid content retained in products.

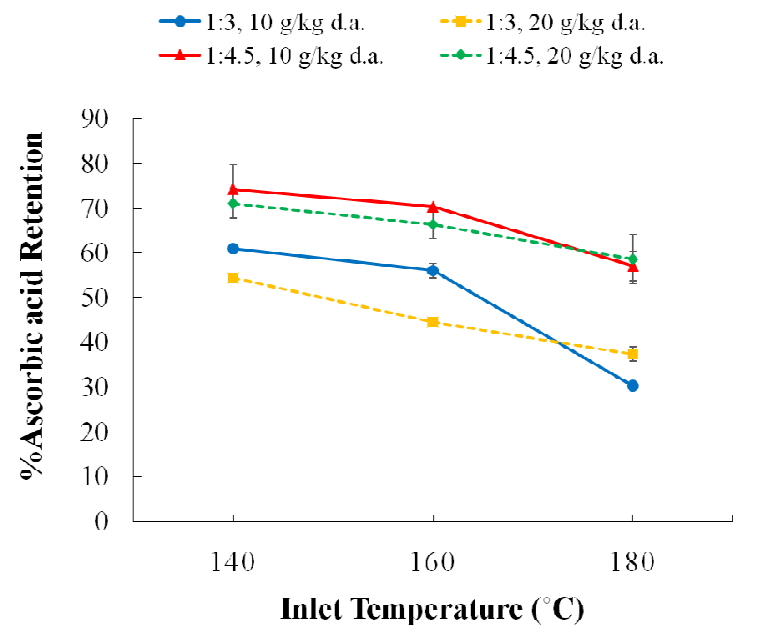

Fig. 4. Ascorbic acid retention of orange juice powder from various spray drying conditions

\section{Powder morphology}

The morphology of some spray dried orange juice powder was observed. Fig. 5 exhibits SEM image of powder illustrated various sizes of irregularly spherical particles with some smooth surface, some shrinkage and indentation which are one of the typical characteristics of particle formation during spray drying. Walton and Mumford (1999) reported that a hollow particle which collapsed and shrivelled, was formed during drying with the particle inflation from bubble nucleation [10].

\section{Conclusions}

The influence of spray drying conditions on the qualities of orange juice powder was examined. Production yield, moisture content and water activity were significantly affected by humidity and inlet drying temperature in this study. The using of low humidity drying air shows the greater production yield. In addition, the ascorbic acid content was significantly affected by maltodextrin concentration and drying temperature. Higher concentration of maltodextrin promotes the ascorbic acid retained in orange juice particles. However, higher drying temperatures lead to lesser of ascorbic acid content.

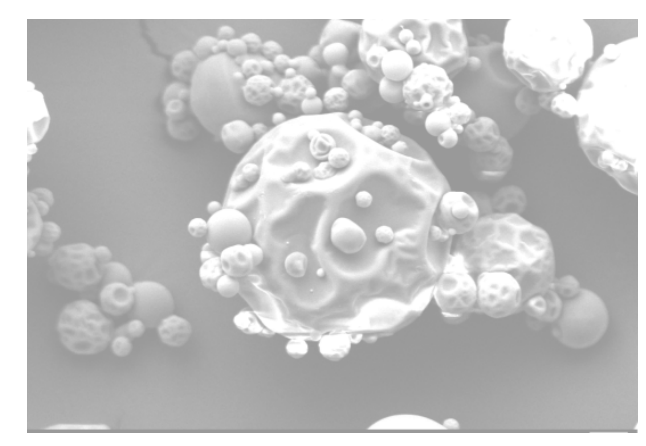

Fig. 5. SEM image (1000x) of spray dried orange juice powder at drying temperature of $160^{\circ} \mathrm{C}$, humidity of $20 \mathrm{~g} / \mathrm{kg}$ dry air and the ratio $\mathrm{O}: \mathrm{M}$ of $1: 4.5$

\section{References}

1. K. Masters, Spray drying handbook, (Longman Scientific \& Technical, New York, 1991)

2. A.K. Shrestha, T. Ua-arak, B.P. Adhikari, T. Howes and B.R. Bhandari, Int J Food Prop., 10, 661-673 (2007)

3. AOAC Method 979.12, Official methods of analysis of AOAC International, (AOAC Int., Arlington, 1995)

4. N. Kingwatee, A. Apichartsrangkoon, P. Chaikham, S. Worametrachanon, J. Techarung, T. Pankasemsuk, LWT-Food Sci Technol, 62, 847853 (2015)

5. H. Amagase, and N.R. Farnsworth, Food Res Int, 44, 1702-1717 (2011)

6. A. M. Goula and K.G. Adamopoulos, Innov Food Sci Emerg Technol, 11, 342-351 (2010)

7. H.A.C. Thijssen, J. Appl. Chem. Biotechnol., 21, 372377 (1971)

8. R.P.Sigh and B.A. Anderson, The major types of food spoilage an overview. In: $R$. Steele (Ed.) Understanding and Measuring the Shelf-life of Food, (CRC Press, Boca Raton, 2000)

9. J.R. Gregory III, Vitamins. In: O.R. Fennema (Ed.) Food Chemistry, (Marcel Dekker, Inc, New York, 1996)

10. D.E. Walton and C.J. Mumford, Transactions of IchemE, 77(A), 442-460 (1999) 